\title{
Benign neglect enhances urban habitat heterogeneity: Responses of vegetation and carabid beetles (Coleoptera: Carabidae) to the cessation of mowing of park lawns
}

\author{
STEPHEN VENN ${ }^{1}$ and D. JOHAN KOTZE ${ }^{2}$ \\ ${ }^{1}$ Department of Biosciences, Faculty of Biological and Environmental Sciences, P.O. Box. 65 (Viikinkaari 1), 00014 University \\ of Helsinki, Finland; e-mail: stephen.venn@helsinki.fi \\ ${ }^{2}$ Department of Environmental Sciences, Faculty of Biological and Environmental Sciences, P.O. Box. 65 (Viikinkaari 2a), \\ 00014 University of Helsinki, Finland; e-mail: johan.kotze@helsinki.fi
}

Key words. Coleoptera, Carabidae, benign neglect, carabid, ground beetles, lawn, park, granivore, urban, vegetation

\begin{abstract}
In this study, we investigate the changes in both vascular plant and carabid beetle assemblages in response to reducing the intensity of management of park lawns in the city of Helsinki. Three levels of mowing were applied to patches of previously managed park lawns: (1) intensively mown, (2) mown until the previous season and unmanaged since, and (3) unmanaged for ten years (benign neglect). The lawns were dominated by plants that disperse vegetatively. This treatment gradient had little or no effect on the flight capability, feeding type or body-size of carabid beetles. However, there was an increase in species richness and the numbers of stenotopic species in the benign neglect treatment. We conclude that benign neglect of open grassland vegetation will result in higher levels of biodiversity than in more intensely managed vegetation. However, we consider it likely that the optimal strategy for maintaining urban biodiversity would be to apply a meadow management regime of mowing once or twice per year and leaving some areas of unmanaged grassland to maintain habitat heterogeneity.
\end{abstract}

\section{INTRODUCTION}

Lawns of frequently mown grass are a prominent feature of most urban parks and gardens, and constitute a large proportion of the urban green space of many cities (Gaston et al., 2005). The primary role of lawns in urban parks is to provide an appropriate substrate for diverse recreational activities, as well as constituting an aesthetically important landscape element. Whilst intensively managed lawns are a favourable foraging habitat for some birds (Gilbert, 1989, p. 257), as well as some species of carabids (Blubaugh et al., 2011), they are generally considered ecological deserts with little value for biodiversity (Gilbert 1989, p. 186; Shwartz et al., 2008). The question is, therefore, whether lawns can be managed in such a way as to remain aesthetically acceptable for private and public use, yet also contribute to urban biodiversity. Haila \& Levins (1992) suggest that benign neglect, a management approach comprising the cessation of habitat management proposed to maintain high species diversity and richness of habitat types in urban landscapes, might be a good principle for maintaining ecological diversity in cities. They argue that a rich assemblage of plant and animal species is capable of establishing populations in urban environments, as long as they are not subjected to intensive management. A number of studies on urban avifaunae, for example, have shown that the presence of patches of unmanaged vegetation is highly beneficial for bird populations (Jokimäki, 1999; Š́lek et al., 2004; Shwartz et al., 2008; Shanahan et al., 2011). Haila \& Levins (1992) propose that there are two benefits of the enhanced species diversity resulting from benign neglect. Firstly, urban residents learn to respect wildlife as a result of their contact with nature. Secondly, they suggest that protected areas alone are inadequate for protecting biodiversity, and that it will be critically important to make anthropogenically modified urban habitats as species rich as possible for "the long term protection of ecological diversity" (Haila \& Levins, 1992). In this study we investigated the effects of "benign neglect" on vascular plant and carabid species richness, following the cessation of mowing of Helsinki park lawns.

Both intensive management and recreational use over an extended period of time exert strong selective pressures on vascular plant communities, resulting in assemblages dominated by stress tolerant species (Kellomäki \& Saastamoinen, 1975; Liddle, 1975; Hamberg et al., 2008). Lawnmowing, in particular, selects for plant species that disperse vegetatively, are low growing, possess a rosette, are annual or biennial and flower early (Elliott, 1988; Forbes et al., 1997; Pykälä, 2001). For epigaeic arthropods of open habitats, such management determines the microclimate and availability of such resources as seeds. Consequently, the most speciose carabid genera of open habitats, Harpalus and Amara (Luff et al., 1989; Mauchline et al., 2004; Venn et al., 2013), which comprise predominantly granivorous (seed-feeding) species (Hengeveld, 1980; Zetto Brandmayr, 1990; Honek et al., 2007; Bohan et al., 2011), are expected to be highly susceptible to lawn management regimes. Whilst the influence of lawn mowing regimes on epigaeic arthropod communities has been little studied, studies of ruderal and brownfield habitats have suggested 
that open urban habitats contain species rich carabid assemblages, which undergo characteristic changes with the successional development of vegetation following disturbance (Schwerk, 2000; Small et al., 2003).

Lawns are generally managed by frequent mowing, and the application of chemical fertilizers and herbicides, and are often also irrigated to maintain a lush and even growth of grass (Gilbert, 1989; Forbes et al., 1997). Such management represents both disturbance (e.g. mowing) and stress for epigaeic arthropod communities, though the resultant microhabitat conditions are likely to be favourable to hygrophilic species in particular. Application of the concept of benign neglect (Haila et al., 1988, 1989; Haila \& Levins, 1992) has resulted in the cessation of intensive management of some urban park lawns for the dual purpose of reducing management costs and enhancing biodiversity.

In this study, our primary objective was to evaluate the responses of field layer vegetation and carabid beetles to the intensity of grassland management by studying intensively-managed lawns, through lawns that were managed until the previous summer, to grasslands that had been unmanaged for 10 years (benign neglect) in Helsinki. We concentrate on carabid beetles, but also provide some information on the responses of field layer vegetation. The following hypotheses are tested. First, we hypothesize that moderately-managed lawns, as well as benign neglect, will have a positive effect on vegetation and carabid species richness, based on evidence presented in support of the Intermediate Disturbance Hypothesis (IDH) (Connell, 1978; Grime \& Mackey, 2002; see also Gray, 1989), and on the observation that grassland carabid beetles are relatively robust to disturbance by mowing and trampling (Morris, 2000; Cole et al., 2006). Furthermore, disturbance-tolerant plant species, and those that spread vegetatively, are expected to dominate lawns. Second, intensively-managed lawns are hypothesized to contain species with better dispersal capacity (Gilbert, 1989; Gray, 1989; Kotze \& O’Hara, 2003; Grime, 2006), as those with poorer dispersal capacity are less able to recolonize after disturbance. Third, we hypothesize that in intensively-managed lawns there will mainly be small species since large species are more susceptible to disturbance (Gray, 1989; Martinson \& Raup, 2013). Fourth, intensively-managed lawns will host fewer granivorous carabid species than moderately-managed lawns and benign neglect, due to fewer resources. Fifth, intensivelymanaged lawns will host more xerophilic species, whereas the benign neglect treatment will have more hygrophilic species. Finally, we expect the benign neglect treatment to contain more stenotopic species and rare species of conservation value and the more disturbed lawns to be dominated by eurytopic species (Czechowski \& Pisarski, 1981; Gray, 1989; Klausnitzer, 1993).

\section{MATERIAL AND METHODS}

\section{Study sites}

Five urban parks in the city of Helsinki $\left(60^{\circ} 10^{\prime} \mathrm{N}, 24^{\circ} 57^{\prime} \mathrm{E}\right)$ (Fig. 1) were included in this study. The selected parks, Töölö Bay Park, Hietaniemi Crematorium Park, Nature House grounds, Sibelius Park and Monk's Park, were predominantly grassed and

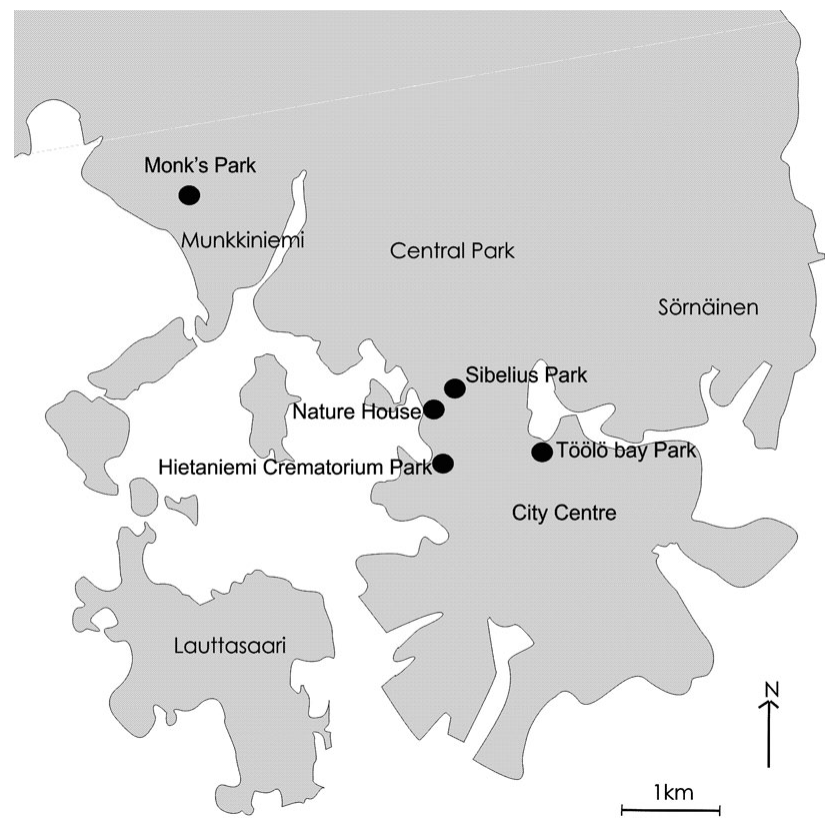

Fig. 1. Map of the region of Helsinki studied. The Baltic Sea is white, land grey and study sites are indicated by black dots.

the lawn areas were used intensively for recreational purposes. Each park contained (i) an area of grassland that had been intensively mown for a number of years previously (intensive management), (ii) an area of formerly mown grassland that had been unmanaged since the end of the previous season (intermediate management) and (iii) an area of formerly mown grassland that had been unmanaged for 10 years previously (benign neglect), except in the Hietaniemi Crematorium Park, in which there was no benign neglect treatment.

\section{Study design}

Epigaeic arthropods were sampled using a total of 143 plastic pitfall traps of $67 \mathrm{~mm}$ mouth-diameter. The traps were placed $10 \mathrm{~m}$ apart in transects of 10 traps per treatment (30 traps per park) (there were 13 pitfall traps in the benign neglect treatment at the Nature House park because trap losses were anticipated) each of which contained propylene glycol (1:1 aqueous) as a preservative. A randomized block design was employed of five parks, each with three treatments, lawn, intermediate and benign neglect, though this was incomplete due to the absence of the benign neglect treatment in one of the parks. Opaque plastic lids of $10 \mathrm{~cm}^{2}$ were placed over the traps to prevent inundation with debris or precipitation. The traps were set on 7 May 2003, emptied monthly and maintained until 16 September 2003. Carabid data were pooled for each treatment (10 pitfall traps) at each site per visit. The trapped carabid beetles were identified to species using Lindroth $(1985,1986)$.

Vegetation was surveyed by means of three $1 \mathrm{~m}^{2}$ quadrats along the $10 \mathrm{~m}$ pitfall transects (one quadrat centrally and one at each end) per treatment per park. Species composition and percentage cover were recorded for all species of vascular plants occurring in each quadrat (Taipale, 2004).

\section{Statistical analyses}

Non-metric multidimensional scaling (NMDS) ordinations were performed on both the vegetation and carabid beetle data, using the statistical packages vegan (Oksanen, 2013) and MASS, in the R statistical software (version 3.0.2, R Development Core Team, 2013). In the NMDS protocol, the iteration is repeated with 


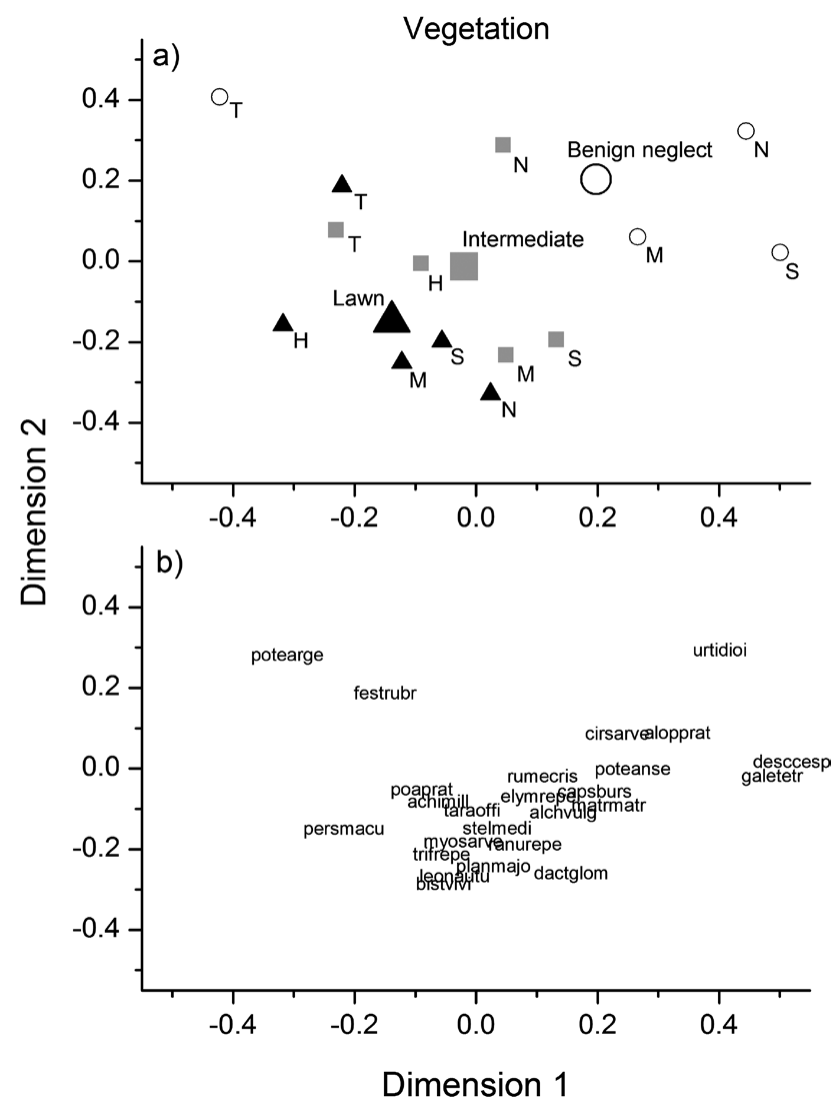

Fig. 2. GNMDS ordination of plant species. Fig. 2a shows the locations of the sites and the centroids (large symbols) of the three treatments, which form a gradient from Lawn (black triangles) through Intermediate (grey squares) to Benign neglect (open circles). Fig. $2 \mathrm{~b}$ shows the ordination of plant species (see Appendix 1 for full species names).

several random starts and a solution with the lowest stress value is selected to ensure that the resulting ordination is optimal as a global solution for the data, rather than optimal for a local subset within the data (Oksanen, 2007). This analysis was used to explore the relationships between plant species assemblages and the three treatments, and carabid species composition and the three treatments. The Bray-Curtis coefficient was used as a dissimilarity measure and permutation tests were used in the vector fitting procedure. The vegetation data comprised the average percentage cover from three $1 \mathrm{~m}^{2}$ quadrats per treatment per park. The cover data for all plant species producing seeds suitable for granivorous carabids were included as site variables in the ordination of the carabid data, to determine possible effects on the occurrences of granivorous carabids at these sites. The carabid data were pooled per treatment per park for the whole season, and standardized to 100 trapping days.

Generalized linear mixed models (GLMM) were applied using the glmer function in the lme4 library in R (R Development Core Team, 2013), to test the effects of treatment on the following carabid beetle parameters: (1) number of carabid species, (2) number of carabid individuals, (3) wing morphology (macropterous, wing dimorphic), (4) body size (four size classes: $<6 \mathrm{~mm}$, $6-7.1,7.1-8.7,>8.7 \mathrm{~mm}$ ), (5) feeding guild (granivorous, predator), (6) moisture affinity (xerophilic, mesophilic, hygrophilic) and (7) specialization (eurytopic, stenotopic). These arbitrary size classes were chosen to ensure relatively even numbers of species per size category. These response variables (overall number of

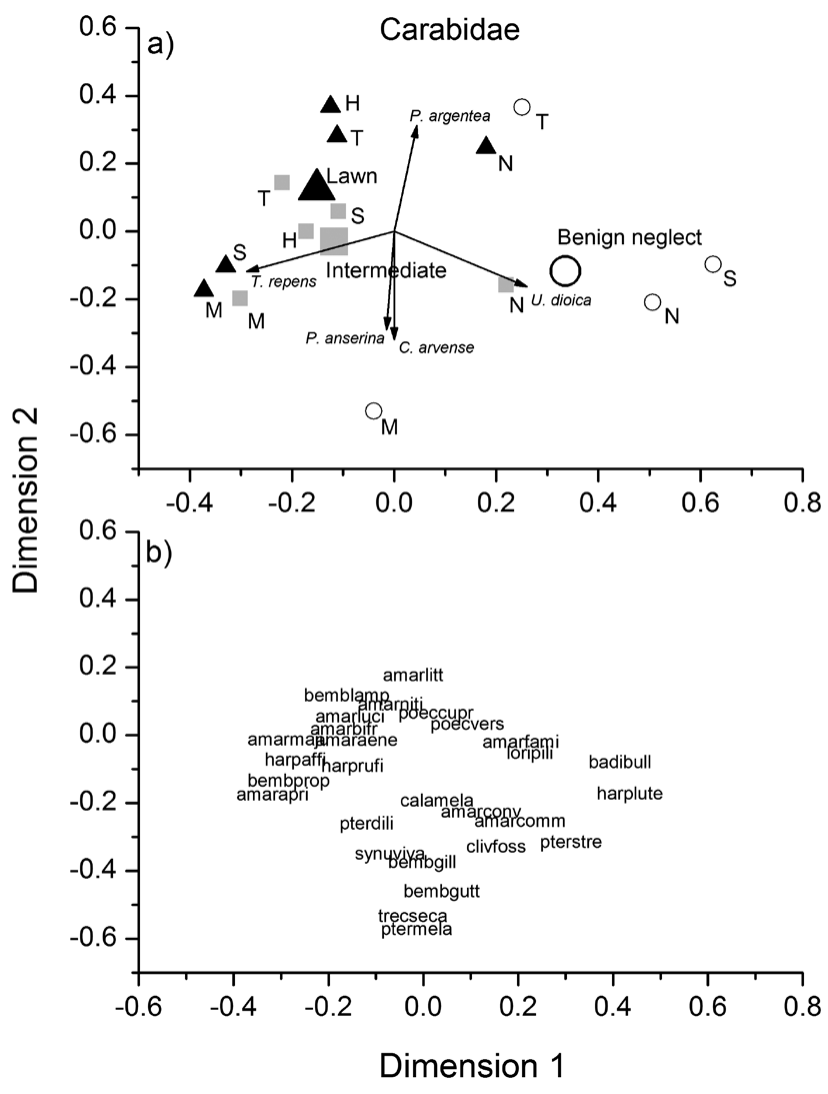

Fig. 3. GNMDS ordination of carabid species. Fig 3a shows the locations of the sites and centroids (large symbols) of the three treatments, which form a gradient from Lawn (black triangles) through Intermediate (grey squares) to Benign neglect (open circles). Vectors are for the five plant species that showed significant correlations with the carabid beetle ordination; Potentilla argentea, Urtica dioica, Cirsium arvense, P. anserina and Trifolium repens. Fig. $3 \mathrm{~b}$ shows the ordination of carabid species (see Appendix 2 for full species names).

species and individuals, and number of species per trait category) were modelled following a Poisson error distribution. Park was added as a random variable. Information on wing morphology, body size, feeding strategy, moisture affinity and specialization, were obtained from the literature (Lindroth, 1985, 1986, 1992; Martinková et al., 2006; Honek et al., 2007; Luff, 2007).

\section{RESULTS}

A total of 54 species of field layer vascular plants were recorded, of which the most abundant were Festuca rubra (8.9\% total cover), Bistorta vivipara $(8.8 \%)$, Polygonum persicaria $(6.5 \%)$ and Taraxacum spp. (6.3\%) (Appendix $1)$. The total catch of carabid beetles consisted of 1902 individuals belonging to 51 species, of which the most abundant were Bembidion properans (28.9\% of total catch), Pterostichus melanarius (14.1\%) and Pseudoophonus rufipes (9.5\%) (Appendix 2).

\section{Vascular plant and carabid beetle assemblages}

The purpose of the vegetation analysis was to evaluate plant response to management intensity and enable us to see whether sites with similar vegetation will have similar carabid assemblages. The GNMDS ordination plot for vegetation (Fig. 2a) shows a relatively strong separation of the 


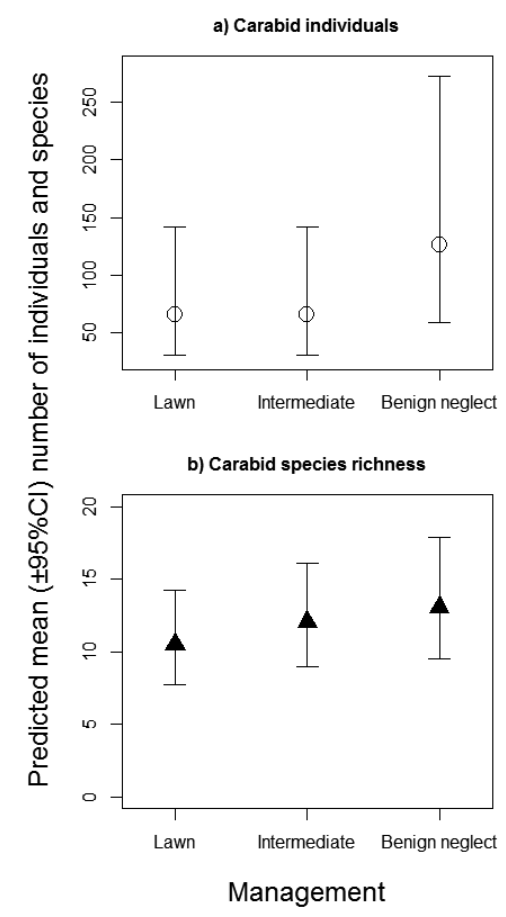

Fig. 4. Plots of the numbers of carabid individuals (a) and species (b) in each treatment predicted by the GLMM. There are significantly more carabid individuals in the benign neglect treatment than either the intermediate or lawn treatments, though no significant differences in the number of species recorded.

treatments $\left(r^{2}=0.27, p=0.081\right)$, with an apparent linear gradient from the most intensively managed lawns at the lower left, through intermediate to benign neglect at the upper right of the ordination space. In terms of species associated with a particular treatment, the following patterns were observed. The lawn treatment was dominated by the plant species Bistorta vivipara, Plantago major, Ranunculus repens and Trifolium repens, all of which are eurytopic and ruderal species with a high tolerance of disturbance and frequently found in park lawns. They are low growing, produce flowers and seeds under intensive management regimes, mostly (3/4) form a rosette and withstand trampling. At the benign neglect end of the gradient, the dominant plant species were Urtica dioica, Deschampsia cespitosa and Galeopsis tetrahit (Fig. 2b). These are taller growing species, which mature and produce seeds more slowly, though they are also eurytopic, ruderal species with a high tolerance of disturbance. A number of species recorded from single sites included additional tall-growing, nitrophilic, ruderal species, such as Anthriscus sylvestris, Aegopodium podagraria, Chenopodium album, and also a number of species that are associated with conservationally important dry meadow habitats, such as Artemisia campestris and Sedum telephium. The only singleton plant species recorded from the lawns was Rumex acetosella, which supports the suggestion that lawns are homogeneous. A total of four singleton species were recorded from the intermediate treatment: Leucanthemum vulgare, Rumex crispus, Ranunculus auricomus and Poa nemoralis.
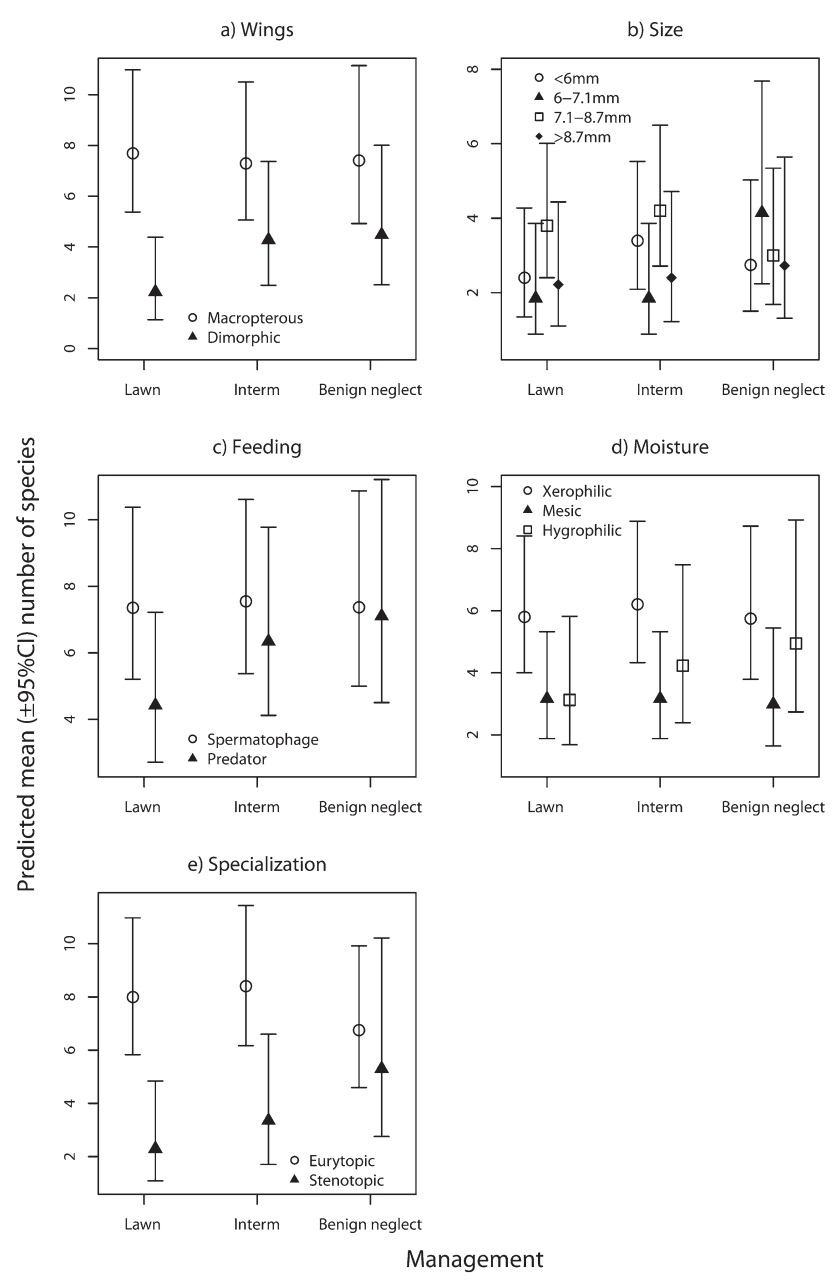

Fig. 5. Numbers of species predicted by the GLMM analysis for species in the following trait groups: a - wing morphology (dimorphic/macropterous); $\mathrm{b}$ - body size (size $1<6 \mathrm{~mm}$, size $2=$ $6<7.1 \mathrm{~mm}$, size $3=7.1 \leq 8.7 \mathrm{~mm}$, size $4>8.7 \mathrm{~mm}$ ); - feeding (granivore/predator); $\mathrm{d}$ - moisture preference (xerophilic/mesic/ hygrophilous) and $\mathrm{e}-$ degree of specialization (eurytopic/stenotopic).

The carabid assemblage also showed a gradient from lawn to benign neglect (Fig. 3a), but here the lawn and intermediate treatments were more similar, while the benign neglect treatment was quite distinct $\left(r^{2}=0.32, p=0.034\right)$. The lawn, and to some degree the intermediate treatments, are characterized by the carabid species Bembidion lampros, together with a considerable number of Amara species, including $A$. littorea, $A$. nitida, $A$. lucida and $A$. bifrons (Fig. 3b). The benign neglect treatment in turn was dominated by Harpalus luteicornis and Pterostichus strenuus. Vectors are shown for the covers of the five seed-bearing plants that were significant $(p<0.1)$. These were Cirsium arvense $\left(r^{2}=0.75, p=0.007\right)$, Trifolium repens $\left(r^{2}=0.49\right.$, $p=0.062)$, Potentilla argentum $\left(r^{2}=0.42, p=0.075\right), P$. anserina $\left(r^{2}=0.54, p=0.082\right)$ and Urtica dioica $\left(r^{2}=0.41\right.$, $p=0.098)$.

\section{Carabid beetle abundance, species richness and traits}

The predicted number of carabid individuals was similar in the lawn and intermediate treatments but was signifi- 
TABLE 1. Generalised linear mixed-effect model results. Significant and near-significant $(p<0.1)$ treatment effects are highlighted in bold. See Figs 4 and 5. The model intercepts represent the benign neglect treatment.

\begin{tabular}{|c|c|c|c|c|c|}
\hline & Treatment & Estimate & SE & z-value & P-value \\
\hline \multirow[t]{3}{*}{ Carabid abundance } & (Intercept) & 4.839 & 0.385 & 12.58 & $<0.001$ \\
\hline & Intermediate & -0.658 & 0.058 & -11.35 & $<0.001$ \\
\hline & Lawn & -0.658 & 0.058 & -11.35 & $<0.001$ \\
\hline \multirow[t]{3}{*}{ Carabid species richness } & (Intercept) & 2.569 & 0.158 & 16.295 & $<0.001$ \\
\hline & Intermediate & -0.080 & 0.191 & -0.415 & 0.678 \\
\hline & Lawn & -0.220 & 0.198 & -1.113 & 0.266 \\
\hline \multicolumn{6}{|l|}{ Wing morphology } \\
\hline \multirow{3}{*}{ Macropterous species } & (Intercept) & 2.002 & 0.204 & 9.804 & $<0.001$ \\
\hline & Intermediate & -0.016 & 0.251 & -0.064 & 0.949 \\
\hline & Lawn & 0.037 & 0.249 & 0.148 & 0.883 \\
\hline \multirow[t]{3}{*}{ Wing dimorphic species } & (Intercept) & 1.500 & 0.290 & 5.179 & $<0.001$ \\
\hline & Intermediate & -0.046 & 0.312 & -0.147 & 0.883 \\
\hline & Lawn & -0.696 & 0.371 & -1.879 & 0.060 \\
\hline \multicolumn{6}{|l|}{$\overline{\text { Size category }}$} \\
\hline \multirow[t]{3}{*}{ Size class $1(<6 \mathrm{~mm})$} & (Intercept) & 1.012 & 0.302 & 3.355 & $<0.001$ \\
\hline & Intermediate & 0.212 & 0.387 & 0.548 & 0.583 \\
\hline & Lawn & -0.056 & 0.410 & -0.137 & 0.891 \\
\hline \multirow{3}{*}{ Size class $2(6-7.1 \mathrm{~mm})$} & (Intercept) & 1.442 & 0.296 & 4.866 & $<0.001$ \\
\hline & Intermediate & -0.812 & 0.403 & -2.014 & 0.044 \\
\hline & Lawn & -0.917 & 0.417 & -2.200 & 0.028 \\
\hline \multirow[t]{3}{*}{ Size class $3(7.1-8.7 \mathrm{~mm})$} & (Intercept) & 1.099 & 0.289 & 3.806 & $<0.001$ \\
\hline & Intermediate & 0.383 & 0.359 & 1.067 & 0.286 \\
\hline & Lawn & 0.337 & 0.362 & 0.930 & 0.352 \\
\hline \multirow[t]{3}{*}{ Size class $4(>8.7 \mathrm{~mm})$} & (Intercept) & 1.009 & 0.343 & 2.938 & 0.003 \\
\hline & Intermediate & -0.184 & 0.427 & -0.432 & 0.666 \\
\hline & Lawn & -0.367 & 0.446 & -0.821 & 0.412 \\
\hline \multicolumn{6}{|l|}{ Feeding guild } \\
\hline \multirow[t]{3}{*}{ Granivorous species } & (Intercept) & 1.997 & 0.194 & 10.276 & $<0.001$ \\
\hline & Intermediate & 0.025 & 0.248 & 0.099 & 0.921 \\
\hline & Lawn & -0.002 & 0.250 & -0.009 & 0.993 \\
\hline \multirow[t]{3}{*}{ Predacious species } & (Intercept) & 1.961 & 0.228 & 8.598 & $<0.001$ \\
\hline & Intermediate & -0.113 & 0.257 & -0.441 & 0.659 \\
\hline & Lawn & -0.474 & 0.282 & -1.685 & 0.092 \\
\hline \multicolumn{6}{|l|}{ Moisture preference } \\
\hline \multirow{3}{*}{ Xerophilic species } & (Intercept) & 1.749 & 0.209 & 8.389 & $<0.001$ \\
\hline & Intermediate & 0.075 & 0.275 & 0.274 & 0.784 \\
\hline & Lawn & 0.009 & 0.279 & 0.031 & 0.975 \\
\hline \multirow[t]{3}{*}{ Mesophilic species } & (Intercept) & 1.095 & 0.299 & 3.656 & $<0.001$ \\
\hline & Intermediate & 0.057 & 0.385 & 0.147 & 0.883 \\
\hline & Lawn & 0.057 & 0.385 & 0.147 & 0.883 \\
\hline \multirow[t]{3}{*}{ Hygrophilic species } & (Intercept) & 1.598 & 0.295 & 5.411 & $<0.001$ \\
\hline & Intermediate & -0.156 & 0.304 & -0.513 & 0.608 \\
\hline & Lawn & -0.459 & 0.329 & -1.393 & 0.164 \\
\hline \multicolumn{6}{|l|}{ Specialization } \\
\hline \multirow[t]{3}{*}{ Eurytopic species } & (Intercept) & 1.910 & 0.193 & 9.922 & $<0.001$ \\
\hline & Intermediate & 0.219 & 0.247 & 0.887 & 0.375 \\
\hline & Lawn & 0.170 & 0.249 & 0.682 & 0.495 \\
\hline \multirow[t]{3}{*}{ Stenotopic species } & (Intercept) & 1.669 & 0.328 & 5.091 & $<0.001$ \\
\hline & Intermediate & -0.458 & 0.312 & -1.469 & 0.142 \\
\hline & Lawn & -0.838 & 0.349 & -2.400 & 0.016 \\
\hline
\end{tabular}

cantly higher in the benign neglect treatment (Table 1, Fig. 4a). Treatment, however, had no significant effect on carabid species richness (Fig. 4b). Sixteen of the carabid species were only trapped from the benign neglect treatment, whereas only four species each were exclusive to the intensively mown lawns and intermediate sites (Appendix 2).

There was no significant difference in the predicted number of macropterous carabid species across treatments, though wing dimorphic species richness appears to be lower in the lawn compared to the benign neglect treatment (Table 1, Fig. 5a). Apart from size class 2 (carabid beetles of 6-7.1 mm), which was significantly more species rich in the benign neglect treatment compared to the other two treatments (Table 1, Fig. 5b), no significant differences were observed in the numbers of species of different sizes across the treatment gradient. 
There was also no significant difference in the predicted numbers of granivorous species across treatments, though the predicted number of predacious species increased along the gradient from lawn to benign neglect (Fig. 5c). There was no significant change in the predicted numbers of xerophilic, mesic or hygrophilic species across the treatments, but there is an apparent increase in the number of hygrophilic species from lawn to benign neglect (Fig. 5d). Regarding specialization, there were significantly fewer stenotopic species in the lawn treatment compared to the treatments with reduced management intensity, through intermediate to benign neglect treatments (Table 1). There was a non-significant reduction in the number of eurytopic species in benign neglect compared to the other two treatments (Fig. 5e).

\section{DISCUSSION}

The carabid fauna of meadow and dry grassland habitats is known to be speciose (Morris, 2000; Żelazna \& Błażejewicz-Zawadzińska, 2005; Blubaugh et al., 2011; Venn et al., 2013). The 51 carabid species recorded in this study represent $23 \%$ of the carabid fauna of the southern Finnish region of Uusimaa, as compared to 78 species in a study of dry meadow habitats of acknowledged conservation value (Venn et al., 2013) and 72 from a diverse range of habitats on golf courses (Saarikivi et al., 2010). The carabid assemblages of open grassland habitats in northern Europe tend to be dominated by the species rich genus Amara, which constituted 19 of the 51 species collected here. These species are typically granivorous, flight capable and xerophilic. Both the vegetation and carabid beetle assemblages (ordination analyses) show distinct separation of the three treatments into a gradient from lawn through intermediate to benign neglect, suggesting that reducing management intensity of park lawns is a viable means of enhancing heterogeneity and species richness. Whilst there was no significant difference in the species richness between the three treatments, the number of individuals was significantly greater in the benign neglect treatment than either of the other two treatments. This is possibly due to the greater complexity of the vegetation structure compared to the short, sparse vegetation of the lawn and intermediate treatments. In a study of species poor hay meadows in the Czech Republic, Cizek et al. (2012) show that heterogenic mowing regimes are favourable for the majority of species in four arthropod taxa studied, butterflies, carabids, orthopterans and spiders.

\section{Plant associations of carabid beetles}

Although we are unable to conclusively demonstrate dependencies between carabid and plant species on the basis of this study, the ordinations do allow us to identify some potential associations. Previous studies on seed preferences have mainly focused on the genera Amara and Harpalus, and suggest that Harpalines tend to be less specialized but favour large seeds, as do large Amara, though the Amara also include some highly specialized granivores. The Harpalinid species Harpalus affinis and Pseudoophonus rufipes have been shown to be generalist granivores, though favouring large seeds, such as those of Chenopodium album, Cirsium arvense, Tripleurospermum inodorum and Taraxacum spp. (Martinkova et al., 2006; Honek et al., 2007). These plant species were mostly recorded from intermediate and benign neglect treatments, though both $H$. affinis and $P$. rufipes were also recorded abundantly from the lawn treatment, so it is unlikely that they are restricted by the availability of seeds of particular plant species.

The plant species Bistorta vivipara, Polygonum persicaria, Leontodon autumnalis, Plantago major, Poa pratensis and Trifolium repens were predominant in the lawn treatment, as were the carabid species Amara apricaria, A. aenea, A. nitida, A. littorea, A. lucida, A. majuscula, Bembidion properans and Harpalus affinis. Of these, $H$. affinis (Honek et al., 2007) and Amara aenea (Saska, 2008; Klimeš \& Saska, 2009) are known to be generalist granivores, consuming seeds of a wide variety of plant species (Saska, 2008).

The intermediate treatment was characterized by the plant species Capsella bursa-pastoralis, Rumex crispus and Stellaria media, and the carabids Pseudoophonus rufipes, H. affinis, Amara bifrons, A. lucida, A. majuscula, Bembidion lampros.

The plants Deschampsia cespitosa, Galeopsis tetrahit, Alopecurus pratensis and Urtica dioica, and the carabids Harpalus luteicornis, Badister bullatus, Clivina fossor and Pterostichus strenuus, characterized the benign neglect treatments. Pterostichus strenuus is described by Lindroth (1986) as favouring habitats with tall herbaceous plants, such as Filipendula ulmaria. Whilst F. ulmaria was not recorded in this study, $P$. strenuus strongly favoured the benign neglect treatment, which had the tallest vegetation structure.

A number of plant species, including Stellaria media and Taraxacum spp., were well represented from all of the treatments, and these are known to be favoured by the carabid species $A$. familiaris (Saska, 2008; Klimeš \& Saska, 2009), and A. apricaria, A. eurynota, A. bifrons and Harpalus luteicornis (Honek et al., 2005, 2007), respectively. The seeds of Stellaria media are favoured by Amara familiaris (Saska, 2008; Klimeš \& Saska, 2009) in particular, and both of these species were well represented in all three treatments.

Incorporating the covers of seed-bearing plant species into the carabid ordination suggested associations with various granivorous carabid species. Numerous Amara species, including Amara littorea and A. nitida, together with Poecilus cupreus and $P$. versicolor, were prevalent at sites with a high cover of Potentilla argentea. Amara apricaria was prevalent at sites dominated by Trifolium repens. Synuchus vivalis was prevalent at sites dominated by Cirsium arvense and Potentilla anserina, whilst Amara convexior and A. communis, together with the harpalinid Harpalus luteicornis, were associated with sites dominated by Urtica dioica (Fig. 3).

\section{Disturbance}

Our first hypothesis was that continuous disturbance resulting from the intensive mowing of lawns would lead 
to increases in disturbance tolerant plant species. This hypothesis is supported by the dominance of a number of low-growing, disturbance tolerant plant species in the lawns and is in keeping with other studies of park lawn vegetation (Grime, 1979). We also hypothesized that the benign neglect treatment would favour stenotopic species and the lawns would contain more eurytopic carabid species. Whilst there was no significant trend in the numbers of eurytopic species, there was, in keeping with this hypothesis, a significantly smaller predicted number of stenotopic species in the lawn treatments $(p=0.016)$. The predicted number of stenotopic species in the intermediate treatment was intermediate, though not significantly less than that of the benign neglect treatment (Table 1, Fig. 5).

We hypothesized that there would be higher species richness in the intermediate treatment, in accordance with the Intermediate Disturbance Hypothesis (Connell, 1978). Our results do not support the hypothesis of greater diversity at the intermediate level of this gradient but rather there is a small increase in species richness with decreasing disturbance (Fig. 4, Table 1). This is in keeping with Wootton (1998), who suggests that whilst species at low trophic levels tend to conform well to the predictions of IDH, mobile competitors and species at higher trophic levels do not.

\section{Dispersal}

We hypothesized that lawns would favour plant species that spread vegetatively, which is a strategy associated with frequent mowing. Indeed the most dominant species in the lawn treatment, Bistorta vivipara, Plantago major, Ranunculus repens and Trifolium repens, all but $P$. major primarily regenerate vegetatively and that species manages to regenerate effectively via seeds, even under intensive mowing. It should also be noted, however, that Urtica dioica, which was dominant in the benign neglect treatment, also regenerates vegetatively, though it is not tolerant of mowing.

A number of previous studies have tested the suggestion that assemblages of disturbed sites contain more highly mobile, flight capable species (Czechowski, 1982; Gray, 1989). Our hypothesis that there would be more macropterous and wing dimorphic species in the lawns was not supported. There was no difference in the numbers of macropterous species across the treatments and there were actually significantly fewer dimorphic species in the lawns. However, this result is not completely reliable, as there were only four brachypterous species in the whole dataset. This is in keeping with the findings of Venn et al. (2013), who note that there are very few brachypterous species in the open habitat carabid fauna of this region, though some of these do occur in urban grasslands.

\section{Body size}

Gray (1989) suggested that environments with high levels of stress are unfavourable for large-bodied organisms and this has been supported by the results of a number of studies of carabids in urban environments (Klausnitzer \& Richter, 1983; Šustek, 1987; Magura et al., 2010), though not universally (see Niemelä \& Kotze, 2009). In the pre- sent study, there was no effect of treatment on the smallest and largest size classes. Carabids of Size 3 were somewhat less abundant in the benign neglect treatment, and those of Class 2 were significantly more abundant in the benign neglect treatment. Whilst the two largest carabid species in this study were collected exclusively from a single benign neglect site, these were two singletons from the same site, and therefore cannot be considered as indicative of a stress effect on the largest carabid species. On the basis of this study there is no evidence of a simple effect of treatment on carabid size. However, our approach of dividing the species into arbitrary size classes is rather coarse and only really suitable for an exploratory investigation of size responses. Šustek (1987) took a more sensitive approach by plotting size distributions of both species and individuals and determined that in assemblages of habitats with minimal anthropogenic disturbance, the size distributions were close to log-normal, whereas those of highly disturbed habitats comprised separate, discontinuous peaks. He suggests that this was due to the simplification of the trophic structure in more disturbed habitats. It is not, however, clear from that study whether the data were standardized for sample size, as the log-normal distribution becomes less likely if sample size is small (Magurran, 2004; Venn et al., 2013).

In a study of carabid assemblages of urban dry meadow habitats in Helsinki, Venn et al. (2013) show that there are more large species in the least disturbed habitat and no significant difference between the numbers of small species in the unmanaged habitats and annually mown meadows, though this may simply indicate that there is little difference between such similarly low levels of disturbance. Blake et al. (1994) also studied this phenomenon using a broader range of disturbance levels and distinguish a clear effect of management level on size distribution, with more small carabids in highly managed habitats and more large carabids in lightly managed habitats. Their data, however, had a strong correlation between management level and altitude, so it is not possible to conclusively determine which of these factors caused the result.

\section{Feeding}

Our hypothesis that high seed production in the benign neglect and intermediate sites, compared to the minimal production in the mown lawn treatment, would result in a strong effect on granivorous carabid species, is not supported. However, there is a suggestive effect on predacious species, for which the predicted number in the lawn treatment is smaller $(p=0.092)$. This suggests that species at higher trophic levels benefit from higher levels of habitat complexity, and the mown lawns offer a poor level of resources for predacious carabid beetles. It is reported that some of the dominant plant species in the lawn treatments have adapted to produce large volumes of seeds, even under regimes of frequent mowing (Samuelsen, 2000), so the provision of such resources as seeds may be as effective in the lawn treatment as in the other treatments. Furthermore, whilst Harpalus spp. and Amara spp. in particular are considered to be primarily granivores, it has also been shown 
that many of these species actually utilize a much broader range of food sources (Klimeš \& Saska, 2009; Lundgren et al., 2013). Specific studies on three Amara species have shown that there is considerable variation in the level of specialization, as indicated by dietary effects on fecundity. Some Amara species require a mixed diet of seeds and insect prey to reproduce effectively, whereas others require the provision of particular seeds (Saska, 2008).

It is suggested that the activity of granivorous carabid species of grassland habitats is correlated with the diversity of plant species present, though with no such effect for predacious carabids (Luff, 1987; Blubaugh et al., 2011). This indicates that there is resource limitation for the granivorous species. Other studies have shown that tall grassland vegetation, whilst having low plant diversity, often has high carabid diversity (Sieren \& Fischer, 2002). Den Boer (1965) suggests that this is simply due to the higher level of structural complexity.

\section{Exposure/Moisture}

The majority of open habitat carabid species are xerophilic and the urban region provides favourable conditions for such species (Venn et al., 2013). We hypothesized that the more open lawn habitat would contain more xerophilic species than the more densely vegetated, intermediate and benign neglect habitats. Our results show no significant difference in the numbers of xerophilic and mesic species across the three treatments, though there was an increase in the number of hygrophilic species from lawn, through intermediate to benign neglect. This suggests that the critical factor for these species is probably the amount of shade rather than moisture level, as the lawns are lusher and moister than the other treatments, though also the most exposed. Lindroth (1986) refers to several xerophilic species being particularly active in bright sunlight, so it would not be surprising if the response of species categorized as hygrophilic would be contrary to that of xerophilic species.

\section{Conservation and specialization level}

None of the carabid species recorded in this study were classed as threatened or endangered. Because a slightly more abundant, species rich (Fig. 4) and specialized (Fig. 5e) assemblage was recorded in the benign neglect patches than the lawns, we conclude that these habitats do make a contribution to urban biodiversity. The vegetation shows similar levels of heterogeneity within the different treatment categories, but there was a considerable change in vegetation structure, even after a single season of benign neglect. A similar response can be seen for carabids, so it is reasonable to suggest that other taxa might respond similarly. Blubaugh et al. (2011) recommend the provision of patches of unmanaged vegetation adjacent to intensively managed lawns, to serve as refugia and facilitate recolonization after disturbance. Also the study of Cizek et al. (2012) reveals that the establishment of patches of unmown grassland, equivalent to the benign neglect in this study, in species poor meadow habitats, has a positive effect on the diversity of four arthropod taxa, including carabid beetles. It is also reported by Muller (1990) that mowing two or three times per season rather than just once resulted in greater levels of plant diversity in lawns undergoing conversion to meadows. This implies that a certain amount of management can result in more species diverse meadows. The benign neglect regime of this study certainly enhanced habitat heterogeneity and provided refugia and habitats for a number of bird and arthropod species. However, if the primary objective is to enhance urban biodiversity, then it would probably be more effective to initiate a regime of mowing 1-3 times per season. In addition to this, it would also be beneficial to leave some patches unmanaged for species that also require such habitats.

Managed dry meadows in Helsinki are known to contain high levels of species richness of both vascular plants (Manninen et al., 2010) and carabid beetles (Venn et al., 2013), and these assemblages are limited by the small size and isolation of suitable habitat patches. Therefore, whilst we conclude that benign neglect of urban lawns enhances the provision of resources that are important for some taxa, and will enhance local species richness, we suggest that management by mowing once or twice per year and the subsequent removal of the mown vegetation, would allow the development of more diverse plant and carabid assemblages, and further enhance urban biodiversity. The optimal strategy for enhancing the biodiversity of urban grasslands would probably be to favour the implementation of meadow management regimes, particularly in regions which already contain isolated meadow habitats, and to supplement these with small areas of benign neglect. It is also pointed out by Morris (2000) that mowing alone is insufficient as a strategy for maintaining meadow assemblages, as many plant and insect taxa are associated with grazing. Whilst the use of livestock to graze urban and recreational sites presents challenges, there are many cases of their being successfully used in this way, which has the additional advantage of not having to dispose of the hay, which can pose problems for municipal meadow management. Meadows managed in these ways also have value for familiarizing urban residents with the ecosystem services provided by urban meadow ecosystems. Finally, we consider that there is a need for further research into the effects of seed predation on the plant diversity of meadow habitats.

ACKNOWLEDGEMENTS. We thank the Finnish Biologist's Society Vanamo for providing funding for this study, K. Rokala for collecting and identifying the carabid beetles and providing the map, T. Taipale for conducting the vegetation surveys and $\mathrm{S}$. Manninen for advice on the interpretation of vegetation data. We are also grateful for valuable comments from the editor M. Konvicka.

\section{REFERENCES}

Blake S., Foster G.N., Eyre M.D. \& Luff M.L. 1994: Effects of habitat type and grassland management practices on the body size distribution of carabid beetles. - Pedobiologia 38: 502-512.

Blubaugh C.K., Caceres V.A., Kaplan I., Larson J., Sadof C.S. \& Richmond D.S. 2011: Ground beetle (Coleoptera: Ca- 
rabidae) phenology, diversity, and response to weed cover in a turfgrass ecosystem. - Environ. Entomol. 40: 1093-1101.

Bohan D.A., Boursault A., Brooks D.R. \& Petit S. 2011: National-scale regulation of the weed seedbank by carabid predators. - J. Appl. Ecol. 48: 888-898.

Cizek O., Zamecnik J., Tropek R., Kocarek P. \& Konvicka M. 2012: Diversification of mowing regime increases arthropods diversity in species-poor cultural hay meadows. - J. Insect Conserv. 16: 215-226.

Cole L.J., Pollock M.L., Robertson D., Holland J.P. \& McCracken D.I. 2006: Carabid (Coleoptera) assemblages in the Scottish uplands: the influence of sheep grazing on ecological structure. - Entomol. Fenn. 17: 229-240.

Connell J.H. 1978: Diversity in tropical rainforests and coral reefs. - Science 199: 1302-1310.

Czechowski W. 1982: Occurrence of carabids (Coleoptera, Carabidae) in the urban greenery of Warsaw according to the land utilization and cultivation. - Mem. Zool. 39: 3-108.

Czechowski W. \& Pisarski B. (eds) 1981: Species composition and origin of the fauna of Warsaw - Part 1. - Mem. Zool. 34 260 pp.

Den Boer P.J. 1965: Verbreitung von Carabiden und ihr Zusammenhang mit Vegetation und Boden. In Tüxen R. (ed.): Biosoziologie. Dr. W. Junk, Den Haag, pp. 172-183 [in German].

Elliott B. 1988: From people's parks to green deserts. — Landsc. Design 171: 13-17.

Forbes S., Cooper D. \& Kendle A. 1997: The history and development of ecological landscape styles. In Kendle A. \& Forbes S. (eds): Urban Nature Conservation - Landscape Management in the Urban Countryside. E \& FN Spon, London, pp. 244-254.

Gaston K., Smith R., Thompson K. \& Warren P. 2005: Urban domestic gardens (II): experimental tests of methods for increasing biodiversity. - Biodiv. Conserv. 14: 395-413.

Gilbert O.L. 1989: The Ecology of Urban Habitats. Chapman \& Hall, London, 369 pp.

GraY J.S. 1989: Effects of environmental stress on species rich assemblages. — Biol. J. Linn. Soc. 37: 19-32.

Grime J.P. 1979: Plant Strategies and Vegetation Processes. John Wiley, Chichester, $417 \mathrm{pp}$.

GRIME J.P. 2006: Trait convergence and trait divergence in herbaceous plant communities: Mechanisms and consequences. J. Veg. Sci. 17: 255-260.

Grime J.P. \& MACKey J.M.L. 2002: The role of plasticity in resource capture by plants. - Evol. Ecol. 16: 299-307.

Haila Y. \& Levins R. 1992: Humanity and Nature: Ecology, Science and Society. Pluto Press, London, 345 pp.

Haila Y., Halme E. \& Somerma P. 1988: Kaupunkiviheriöiden ekologisen monipuolisuuden arviointi. Pääkaupunkiseudulla suoritetun kaupunkiekologisen tutkimuksen väliraportti. [Evaluating the Ecological Diversity of Urban Green Space.] Helsinki municipality publications C 1988:8. YTV-SAD. 39 pp. [in Finnish].

Haila Y., Tonteri T., Halme E. \& Somerma P. 1989: Kaupunkiviheriöiden kasvillisuuden vaihtelu hyönteisten esiintymistä määräävänä tekijänä. [Variability of vegetation in urban green spaces as a factor affecting insect distribution.] Report of Urban Ecological Research in Helsinki 1987-1988. Helsinki City City Planning Department Master Plan Department publication YB 5/1989. Helsinki Municipality Publications C 1989:4. YTV-SAD. 51 pp. [in Finnish].

Hamberg L., Lehvävirta S., Malmivaara-Lämsä M., Rita H. \& Kотze D.J. 2008: The effects of habitat edges and trampling on understorey vegetation in urban forests in Helsinki, Finland. Appl. Veg. Sci. 11: 83-98.
Hengeveld R. 1980: Polyphagy, oligophagy and food specialization in ground beetles (Coleoptera, Carabidae). - Neth. J. Zool. 30: 564-584.

Honek A., Martinkova Z. \& SASKa P. 2005: Post-dispersal predation of Taraxacum officinale (dandelion) seed. - J. Ecol. 93: 345-352.

Honek A., Martinkova Z., Saska P. \& Pekar S. 2007: Size and taxonomic constraints determine the seed preferences of Carabidae (Coleoptera). — Basic Appl. Ecol. 8: 343-353.

JOKIMÄKI J. 1999: Occurrence of breeding bird species in urban parks: Effects of park structure and broad-scale ariables. - Urban Ecosyst. 3: 21-34.

KellomäKi S. \& SaAstamoinen V.-L. 1975: Trampling tolerance of forest vegetation. - Acta Forest. Fenn. 147: 1-22.

Klausnitzer B. 1993: Ökologie der Grossestadtfauna. 2nd ed. Gustav Fischer, Stuttgart, 454 pp.

Klausnitzer B. \& Richter K. 1983: Presence of an urban gradient demonstrated for carabid associations. - Oecologia (Berlin) 59: 79-82.

KLIMEŠ P. \& SASKA P. 2009: Larval and adult seed consumption affected by the degree of food specialization in Amara (Coleoptera: Carabidae). — J. Appl. Entomol. 134: 659-666.

Kotze D.J. \& O'Hara R.B. 2003: Species decline - but why? Explanations of carabid beetle (Coleoptera, Carabidae) declines in Europe. - Oecologia 135: 138-148.

LidDLE M.J. 1975: A selective review of the ecological effects of human trampling on natural ecosystems. - Biol. Conserv. 7: $17-36$.

Lindroth C.H. 1985: The Carabidae (Coleoptera) of Fennoscandia and Denmark. Vol. 15, Part 1. Fauna Entomologica Skandinavica, E.J. Brill, Leiden, Kopenhagen, pp. 1-225 pp.

Lindroth C.H. 1986: The Carabidae (Coleoptera) of Fennoscandia and Denmark. Vol. 15, Part 2. Fauna Entomologica Skandinavica, E.J. Brill, Leiden, Kopenhagen, pp. 226-497.

Lindroth C.H. 1992: Ground Beetles (Carabidae) of Fennoscandia. Smithsonian Institution, Washington, D.C., 814 pp.

LuFF M.L. 1987: Biology of polyphagous ground beetles in agriculture. In Russell G.E. (ed.): Agricultural Zoology Reviews 2. Intercept, Dorset, pp. 237-278.

Luff M.L. 2007: The Carabidae (Ground Beetles) of Britain and Ireland. Royal Entmological Society and Field Studies Council, St. Albans, 247 pp.

Luff M.L., Eyre M.D. \& Rushton S.P. 1989: Classification and ordination of habitats of ground beetles (Coleoptera, Carabidae) in North-East England. - J. Biogeogr. 16: 121-130.

Lundgren J., SAsKa P. \& Honek A. 2013: Molecular approach to describing a seed-based food web: the post-dispersal granivore community of an invasive plant. - Ecol. Evol. 3: 1642-1652.

Magura T., LöVei G.L. \& Tóthmérész B. 2010: Does urbanisation decrease diversity in ground beetle (Carabidae) assemblages? - Global Ecol. Biogeogr. 19: 16-26.

Magurran A.E. 2004: Measuring Biological Diversity. Blackwell, Oxford, $257 \mathrm{pp}$.

Manninen S., Forss S. \& Venn S.J. 2010: Management mitigates the impact of urbanization on meadow vegetation. - Urban Ecosyst. 13: 461-481.

Mauchline A.L., Watson S.J., Brown V.K. \& Froud-Williams R.J. 2004: Post-dispersal seed predation of non-target weeds in arable crops. - Weed Res. 45: 157-164.

Martinková Z., Saska P. \& HonĚK A. 2006: Consumption of fresh and buried seed by ground beetles (Coleoptera: Carabidae). - Eur. J. Entomol. 103: 361-364.

Martinson H.M. \& Raup M.J. 2013: A meta-analysis of the effects of urbanization on ground beetle communities. Eco- 
sphere 4:60 http://dx.doi.org/10.1890/ES12-00262.1, accessed 06:08:2014.

Morris M.G. 2000: The effects of structure and its dynamics on the ecology and conservation of arthropods in British grasslands. - Biol. Conserv. 95: 129-142.

Muller N. 1990: Development of plant growth in park lawns after conversion to meadow cutting. Results of 5 years' observations of permanent lawns. - Rasen-Turf-Gazon 21: 3-10.

Niemelä J. \& Kotze D.J. 2009: Carabid beetle assemblages along urban to rural gradients: A review. - Landsc. Urban Plan. 92: $65-71$.

OKSANEN J. 2007: VEGAN: An Introduction to Ordination. http:// informatics.nescent.org/wg/phyloinformatics/images/f/f8/Intro-vegan.pdf, accessed 06:08:2014.

Oksanen J. 2013: Multivariate Analysis of Ecological Communities in R: Vegan Tutorial. http://cc.oulu.fi/ jarioksa/opetus/ metodi/vegantutor.pdf, accessed 06:08:2014.

PYKäLÄ J. 2001: Perinteinen karjatalous luonnon monimuotoisuuden ylläpitäjänä. [Traditional Animal Husbandry as a Maintainer of Biodiversity.] Finnish Environment Institute, Vammala Press, Vammala, 205 pp. [in Finnish].

R Development Core Team 2013: R: A Language and Environment for Statistical Computing. R Foundation for Statistical Computing, Vienna, URL http://www.R-project.org.

SaArikivi J., Idström L., Venn S., Niemelä J. \& Kotze D.J. 2010: Carabid beetle assemblages associated with urban golf courses in the greater Helsinki area. - Eur. J. Entomol. 107: 553-561.

Šálek M., Marhoul P., Pintir J., Kopecky T. \& Slaby L. 2004 Importance of unmanaged wasteland patches for the grey partridge Perdix perdix in suburban habitats. - Acta Oecol. 25: 23-33.

Samuelsen A.B. 2000: The traditional uses, chemical constituents and biological activities of Plantago major L. A review. $-J$. Ethnopharmacol. 77(1-2): 1.

SASKA P. 2008: Effect of diet on the fecundity of three carabid beetles. - Physiol. Entomol. 33: 188-192.

SCHWERK A. 2000: Ecological aspects of carabid beetle coenoses (Coleoptera: Carabidae) on industrial fallow grounds in the Ruhr Valley Area. In Brandmayr P., Lovei G.A., Casale A.,
Vigne Taglianti A. \& Zetto T. (eds): Natural History and Applied Ecology of Carabid Beetles. Pensoft, Sofia, Moscow, pp. 277-287.

Shanahan D.F., Miller C., Possingham H.P. \& Fuller R.A. 2011: The influence of patch area and connectivity on avian communities in urban revegetation. - Biol. Conserv. 144: 722-729.

Shwartz A., Shirley S. \& KarK S. 2008: How do habitat variability and management regime shape the spatial heterogeneity of birds within a large Mediterranean urban park? - Landsc. Urban Plan. 84: 219-229.

Sieren E. \& Fischer F.P. 2002: Evaluation of measures for enlargement, renaturation and development of a dry grassland biotope by analysing differences in the carabid fauna (Coleoptera). - Acta Oecol. 23: 1-12.

Small E., Sadler J. \& Telfer M. 2003: Carabid assemblages on urban derelict sites in Birmingham, UK. - J. Insect Conserv. 6: 233-246.

ŠUSTEK Z. 1987: Changes in body size structure of carabid communities (Coleoptera, Carabidae) along an urbanisation gradient. - Biologia (Bratislava) 42: 145-156.

TAIPALE T. 2004: Hoitotoimien vaikutus puistojen kasvilajistoon. [The Effect of Management on Park Vegetation.] Unpubl. report [in Finnish].

Venn S.J., Kotze D.J., Lassila T. \& Niemelä J.K. 2013: Urban dry meadows provide valuable habitat for granivorous and xerophylic carabid beetles. - J. Insect Conserv. 17: 747-764.

WootTon J.T. 1998: Effects of disturbance on species diversity: a multitrophic perspective. - Am. Nat. 152: 803-825.

Żelazna E. \& BŁażEJewicZ-ZawadZińsKa M. 2005: Species diversity of carabids (Coleoptera, Carabidae) in different types of Bydgoszcz urban green belts and suburban environments. Folia Biol. (Kraków) (Suppl.) 53: 179-186.

ZetTo Brandmayr T. 1990: Spermophagous (seed-eating) ground beetles: first comparison of the diet and ecology of the harpaline genera Harpalus and Ophonus (Col., Carabidae). In Stork N. (ed.): The Role of Ground Beetles in Ecological and Environmental Studies. Intercept, Andover, pp. 307-316.

Received August 7, 2014; revised and accepted September 24, 2014 Prepublished online October 10, 2014 
ApPENDIX 1. Plant species recorded from three treatments (Lawn, Intermediate and Benign neglect) in five parks (Hietaniemi H, Monks' Park M, Nature House N, Sibelius Park S and Töölö T) in Helsinki. The values are averages of the percentage cover recorded from three $1 \mathrm{~m}^{2}$ quadrats per treatment. The second column contains the abbreviated names of the plant species.

\begin{tabular}{|c|c|c|c|c|c|c|c|c|c|}
\hline & Abbreviation & $\mathrm{H}$ & $\mathrm{M}$ & $\mathrm{N}$ & $\mathrm{S}$ & $\mathrm{T}$ & Lawn & Inter & Benign \\
\hline Trifolium repens & trirep & 2.33 & 5.78 & 1.73 & 2.33 & 0.22 & 3.40 & 1.68 & 0.50 \\
\hline Poa pratensis & poapra & 5.33 & 19.44 & 3.33 & 40.00 & 20.67 & 20.87 & 11.13 & 3.75 \\
\hline Taraxacum officinale & taroff & 7.53 & 5.78 & 14.67 & 6.67 & 4.83 & 5.98 & 9.20 & 1.83 \\
\hline Festuca rubra & fesrub & 6.67 & 0.00 & 33.33 & 0.00 & 23.89 & 7.67 & 12.67 & 4.17 \\
\hline Potentilla argentea coll. & potarg & 0.00 & 0.00 & 0.00 & 0.00 & 4.13 & 1.00 & 0.13 & 1.68 \\
\hline Rumex acetosella & rumacl & 0.00 & 0.00 & 0.00 & 0.00 & 0.02 & 0.01 & 0.00 & 0.00 \\
\hline Galeopsis sp. & galspp & 0.00 & 0.00 & 0.00 & 0.00 & 0.22 & 0.13 & 0.00 & 0.00 \\
\hline Matricaria matricarioides & matmat & 0.00 & 0.56 & 0.00 & 0.00 & 2.22 & 0.00 & 1.67 & 0.42 \\
\hline Leucanthemum vulgare & luevul & 0.00 & 0.00 & 0.00 & 0.00 & 0.02 & 0.00 & 0.01 & 0.00 \\
\hline Plantago major & plamaj & 0.00 & 6.67 & 2.67 & 2.33 & 0.44 & 1.67 & 4.07 & 0.00 \\
\hline Achillea millefolium & achmil & 9.50 & 0.00 & 36.67 & 6.67 & 1.13 & 8.13 & 4.67 & 0.43 \\
\hline Vicia cracca & viccra & 0.00 & 0.00 & 0.00 & 0.00 & 0.06 & 0.00 & 0.00 & 0.04 \\
\hline Epilobium angustifolium & epiang & 0.00 & 0.00 & 0.00 & 0.00 & 1.11 & 0.00 & 0.00 & 0.83 \\
\hline Calamagrostis epigejos & calepi & 0.00 & 0.00 & 0.00 & 0.00 & 11.67 & 0.00 & 0.00 & 8.75 \\
\hline Rumex acetosa & rumacs & 0.00 & 0.00 & 0.00 & 0.00 & 1.11 & 0.00 & 0.00 & 0.83 \\
\hline Artemisia campestris & artcam & 0.00 & 0.00 & 0.00 & 0.00 & 3.89 & 0.00 & 0.00 & 2.92 \\
\hline Lupinus sp. & lupspp & 0.00 & 0.00 & 0.00 & 0.00 & 0.22 & 0.00 & 0.00 & 0.17 \\
\hline Capsella bursa-pastoralis & capbur & 0.87 & 0.00 & 0.00 & 0.00 & 0.00 & 0.01 & 0.55 & 0.42 \\
\hline Stellaria media & stemed & 25.00 & 4.22 & 18.67 & 15.00 & 0.00 & 7.07 & 19.33 & 1.25 \\
\hline Polygonum persicaria & polmac & 40.00 & 0.00 & 0.00 & 0.00 & 0.00 & 12.67 & 4.67 & 0.00 \\
\hline Bistorta vivipara & bisviv & 0.00 & 23.89 & 20.00 & 18.00 & 0.00 & 19.27 & 4.00 & 0.00 \\
\hline Dactylis glomerata & dacglo & 0.00 & 0.00 & 15.00 & 0.00 & 0.00 & 3.00 & 0.00 & 1.25 \\
\hline Alchemilla vulgaris & alcvul & 0.00 & 0.00 & 7.33 & 3.33 & 0.00 & 1.47 & 0.15 & 0.83 \\
\hline Leontodon autumnalis & leoaut & 0.83 & 1.11 & 2.50 & 0.00 & 0.00 & 1.17 & 0.67 & 0.00 \\
\hline Galeopsis tetrahit & galtet & 0.00 & 0.02 & 0.07 & 0.00 & 0.00 & 0.01 & 0.00 & 0.43 \\
\hline Potentilla anserina & potans & 0.00 & 4.44 & 1.67 & 0.00 & 0.00 & 0.33 & 0.00 & 3.33 \\
\hline Ceratodon purpureus & cerpur & 0.00 & 0.00 & 1.33 & 0.00 & 0.00 & 0.00 & 0.00 & 0.33 \\
\hline Ranunculus repens & ranrep & 0.00 & 2.44 & 1.00 & 0.00 & 0.00 & 0.07 & 1.47 & 0.17 \\
\hline Urtica dioica & urtdio & 0.00 & 0.17 & 36.67 & 0.00 & 0.00 & 0.00 & 1.00 & 8.04 \\
\hline Alopecurus pratensis & alopra & 0.00 & 16.11 & 50.00 & 3.33 & 0.00 & 0.67 & 6.67 & 28.33 \\
\hline Rumex crispus & rumcri & 0.00 & 0.00 & 3.33 & 0.00 & 0.00 & 0.00 & 1.67 & 0.00 \\
\hline Ranunculus auricomus & ranaur & 0.00 & 0.00 & 0.33 & 0.00 & 0.00 & 0.00 & 0.07 & 0.00 \\
\hline Cirsium arvense & cirarv & 0.00 & 2.22 & 1.67 & 0.00 & 0.00 & 0.00 & 0.33 & 1.67 \\
\hline Poa nemoralis & poanem & 0.00 & 0.00 & 0.33 & 0.00 & 0.00 & 0.00 & 0.07 & 0.00 \\
\hline Myosotis arvensis & myoarv & 0.00 & 0.00 & 0.07 & 0.67 & 0.00 & 0.13 & 0.05 & 0.00 \\
\hline Deschampsia cespitosa & desces & 0.00 & 0.00 & 0.67 & 0.00 & 0.00 & 0.00 & 0.00 & 6.83 \\
\hline Anthriscus sylvestris & antsyl & 0.00 & 0.00 & 15.00 & 0.00 & 0.00 & 0.00 & 0.00 & 3.75 \\
\hline Acer platanoides & acepla & 0.00 & 0.00 & 1.67 & 0.00 & 0.00 & 0.00 & 0.00 & 0.67 \\
\hline Cirsium vulgare & cirvul & 0.00 & 0.00 & 6.67 & 0.00 & 0.00 & 0.00 & 0.00 & 1.67 \\
\hline Equisetum sylvaticum & equsyl & 0.00 & 0.00 & 1.67 & 0.00 & 0.00 & 0.00 & 0.00 & 0.42 \\
\hline Aegopodium podagraria & aegpod & 0.00 & 0.00 & 12.33 & 0.00 & 0.00 & 0.00 & 0.00 & 3.08 \\
\hline Elymus repens & elyrep & 0.00 & 5.00 & 0.00 & 0.00 & 2.78 & 0.67 & 5.00 & 2.92 \\
\hline Chenopodium album & chealb & 0.00 & 0.06 & 0.00 & 0.00 & 0.00 & 0.00 & 0.00 & 0.04 \\
\hline Trifolium pratense & tripra & 0.00 & 0.56 & 0.00 & 0.00 & 0.00 & 0.00 & 0.00 & 0.42 \\
\hline Glechoma hederacea & glehed & 0.00 & 0.00 & 0.00 & 0.00 & 0.00 & 0.00 & 0.00 & 0.02 \\
\hline Prunus padus & prupad & 0.00 & 0.00 & 0.00 & 0.00 & 0.00 & 0.00 & 0.00 & 0.83 \\
\hline Calystegia sepium & calsep & 0.00 & 0.00 & 0.00 & 0.00 & 0.00 & 0.00 & 0.00 & 0.83 \\
\hline Sedum telephium & sedtel & 0.00 & 0.00 & 0.00 & 0.00 & 0.00 & 0.00 & 0.00 & 1.25 \\
\hline Tanacetum vulgare & tanvul & 0.00 & 0.00 & 0.00 & 0.00 & 0.00 & 0.00 & 0.00 & 0.00 \\
\hline Conyza canadensis & concan & 0.00 & 0.00 & 0.00 & 0.00 & 0.00 & 0.00 & 0.00 & 0.00 \\
\hline Populus tremula & poptre & 0.00 & 0.00 & 3.33 & 0.00 & 0.00 & 0.00 & 0.67 & 0.00 \\
\hline Ulmus glabra & ulmgla & 0.00 & 0.00 & 0.67 & 0.00 & 0.00 & 0.00 & 0.13 & 0.00 \\
\hline Bidens tripartita & bidtri & 0.00 & 0.00 & 0.00 & 0.00 & 0.00 & 0.00 & 1.33 & 0.00 \\
\hline Scleranthus annuus & scann & 0.00 & 0.00 & 0.00 & 0.00 & 0.00 & 0.00 & 0.33 & 0.00 \\
\hline
\end{tabular}


ApPENDIX 2. Carabid beetle species recorded from three treatments (Lawn, Intermediate and Benign neglect) in five parks (Hietaniemi H, Monks' Park M, Nature House N, Sibelius Park S and Töölö T) in Helsinki. The values are the pooled number of individuals recorded per park or treatment for each species. The second column contains the abbreviated names of the carabid species. Subsequent columns contain data for the following species traits used in the analyses: Feeding type (Predator/Granivore), wing morphology (Macropterous/ Dimorphic/ Brachypterous), moisture preference (Hygrophilic/Mesophilic/Xerophilic), size class $(1<6 \mathrm{~mm}, 2=6-7.1,3=7.1-8.7$ and $4>8.7 \mathrm{~mm}$ ) and habitat specialization (Eurytopic/Stenotopic). Empty cells are for species for which the necessary information was not available.

\section{章

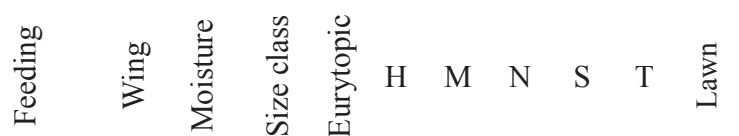

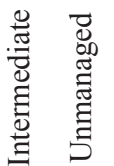

Agonum fuliginosum (Panzer, 1809)

Agonum thoreyi Dejean, 1828

Amara aenea (De Geer, 1774)

Amara apricaria (Paykull, 1790)

Amara bifrons (Gyllenhal, 1810)

Amara brunnea (Gyllenhal, 1810)

Amara communis (Panzer, 1797)

Amara convexior Stephens, 1828

Amara consularis (Duftschmid, 1812)

Amara crenata Dejean, 1828

Amara familiaris (Duftschmid, 1812)

Amara fusca Dejean, 1828

Amara infima (Duftschmid, 1812)

Amara littorea Thomson, 1858

Amara lucida (Duftschmid, 1812)

Amara lunicollis Schiødte, 1837

Amara majuscula (Chaudoir, 1850)

Amara municipalis (Duftschmid, 1812)

Amara nitida Sturm, 1825

Amara plebeja (Gyllenhal, 1810)

Amara tibialis (Paykull, 1798)

Badister bullatus (Schrank, 1798)

Bembidion gilvipes Sturm, 1825

Bembidion guttula (Fabricius, 1792)

Bembidion lampros (Herbst, 1784)

Bembidion mannerheimii Sahlberg, 1827

Bembidion properans (Stephens, 1828)

Bembidion quadrimaculatum (Linnaeus, 1761)

Calathus erratus (Sahlberg, 1827)

Calathus melanocephalus (Linnaeus, 1758)

Calathus micropterus (Duftschmid, 1812)

Carabus nemoralis Müller, 1764

Clivina fossor (Linnaeus, 1758)

Curtonotus aulicus (Panzer, 1796)

Harpalus affinis (Schrank, 1781)

Harpalus luteicornis (Duftschmid, 1812)

Loricera pilicornis (Fabricius, 1775)

Ophonus rufibarbis (Fabricius, 1792)

Platinus assimilis (Paykull, 1790)

Poecilus cupreus (Linnaeus, 1758)

Poecilus versicolor (Sturm, 1824)

Pseudoophonus rufipes (De Geer, 1774)

Pterostichus diligens (Sturm, 1824)

Pterostichus melanarius (Illiger, 1798)

Pterostichus niger (Schaller, 1783)

Pterostichus oblongopunctatus (Fabricius, 1787)

Pterostichus strenuus (Panzer, 1796)

Syntomus truncatellus (Linnaeus, 1761)

Synunchus vivalis (Illiger, 1798)

Trechoblemus micros (Herbst, 1784)

Epaphius secalis (Paykull, 1790)

\begin{tabular}{|c|c|c|c|c|c|c|c|c|c|c|c|c|c|}
\hline agonfuli & Pred & $\mathrm{D}$ & $\mathrm{H}$ & 2 & 0 & 0 & 0 & 1 & 0 & 0 & 0 & 0 & 1 \\
\hline agonthor & Pred & M & $\mathrm{H}$ & 2 & 0 & 0 & 0 & 4 & 0 & 0 & 0 & 0 & 4 \\
\hline amaraene & Grani & M & X & 3 & 0 & 25 & 29 & 5 & 17 & 7 & 41 & 36 & 6 \\
\hline amarapri & Grani & M & $X$ & 3 & 1 & 2 & 77 & 1 & 7 & 3 & 68 & 22 & 0 \\
\hline amarbifr & Grani & M & $\mathrm{X}$ & 2 & 0 & 1 & 1 & 1 & 1 & 2 & 3 & 3 & 0 \\
\hline amarbrun & Grani & M & M & 1 & 1 & 0 & 0 & 1 & 0 & 0 & 1 & 0 & 0 \\
\hline arcomm & Grani & M & $\mathrm{X}$ & 2 & 1 & 1 & 8 & 17 & 3 & 0 & 2 & 11 & 16 \\
\hline narconv & Grani & M & & 3 & 0 & 0 & 4 & 2 & 3 & 1 & 1 & 2 & 7 \\
\hline narcons & Grani & M & $X$ & 4 & 0 & 0 & 1 & 0 & 0 & 0 & 1 & 0 & 0 \\
\hline amarcren & Grani & M & $\mathrm{X}$ & 3 & 0 & 0 & 0 & 0 & 1 & 0 & 1 & 0 & 0 \\
\hline amarfami & Grani & M & $\mathrm{H}$ & 2 & 0 & 3 & 0 & 5 & 2 & 0 & 2 & 4 & 4 \\
\hline amarfusc & Grani & M & $X$ & 3 & 0 & 2 & 0 & 0 & 0 & 0 & 0 & 2 & 0 \\
\hline amarinfi & Grani & $\mathrm{D}$ & $X$ & 1 & 0 & 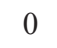 & 1 & 0 & 0 & 0 & 0 & 0 & 1 \\
\hline amarlitt & Grani & M & $X$ & 3 & 0 & 2 & 0 & 0 & 1 & 1 & 1 & 2 & 1 \\
\hline amarluci & Grani & M & $X$ & 1 & 0 & 5 & 0 & 0 & 3 & 0 & 2 & 6 & 0 \\
\hline amarluni & Grani & M & M & 3 & 1 & 0 & 0 & 4 & 0 & 0 & 0 & 0 & 4 \\
\hline narmaja & Grani & M & M & 4 & 0 & 1 & 2 & 0 & 0 & 0 & 2 & 1 & 0 \\
\hline narmuni & Grani & M & $X$ & 2 & 0 & 0 & 0 & 0 & 0 & 2 & 0 & 0 & 2 \\
\hline amarniti & Grani & M & $X$ & 3 & 1 & 1 & 0 & 0 & 1 & 1 & 1 & 1 & 1 \\
\hline amarpleb & Grani & M & $\mathrm{M}, \mathrm{H}$ & 2 & 1 & 1 & 0 & 0 & 0 & 0 & 1 & 0 & 0 \\
\hline amartibi & Grani & M & X & 1 & 0 & 0 & 0 & 1 & 0 & 0 & 0 & 0 & 1 \\
\hline badibull & Pred & M & $\mathrm{M}, \mathrm{H}$ & 1 & 1 & 0 & 0 & 3 & 0 & 0 & 1 & 0 & 2 \\
\hline bemb & Pred & $\mathrm{D}$ & $\mathrm{H}$ & 1 & 0 & 1 & 27 & 9 & 1 & 2 & 0 & 17 & 23 \\
\hline embgutt & Pred & $\mathrm{D}$ & $\mathrm{H}$ & 1 & 0 & 0 & 104 & 31 & 1 & 0 & 2 & 30 & 104 \\
\hline mblamp & Pre & $\mathrm{D}$ & $\mathrm{X}$ & 1 & 1 & 0 & 0 & 0 & 1 & 2 & 0 & 3 & 0 \\
\hline ann & $\operatorname{Pr}$ & $\mathrm{D}$ & $\mathrm{H}$ & 1 & 0 & 0 & 1 & 0 & 0 & 0 & 0 & 0 & 1 \\
\hline bembprop & $\operatorname{Pr}$ & $\mathrm{D}$ & $\mathrm{M}, \mathrm{H}$ & 1 & 0 & 32 & 327 & 3 & 123 & 14 & 281 & 212 & 6 \\
\hline bembquad & Pred & M & $\mathrm{M}, \mathrm{H}$ & 1 & 1 & 0 & 0 & 0 & 0 & 1 & 0 & 1 & 0 \\
\hline calae & $\operatorname{Pr}$ & $\mathrm{D}$ & X & 4 & 1 & 0 & 0 & 0 & 0 & 1 & 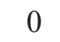 & 0 & 1 \\
\hline calamela & $\operatorname{Pr}$ & $\mathrm{D}$ & $\mathrm{X}$ & 3 & 1 & 6 & 15 & 21 & 3 & 0 & 4 & 34 & 7 \\
\hline calamicr & Pre & B & $\mathrm{X}$ & 4 & 0 & 0 & 0 & 0 & 0 & 8 & 0 & 0 & 8 \\
\hline caranemo & Pred & $\mathrm{D}$ & M & 4 & 1 & 0 & , & 0 & 0 & 0 & 0 & 0 & 9 \\
\hline clivfoss & Grani/Pred & $\mathrm{D}$ & $\mathrm{H}$ & 1 & 1 & 0 & 6 & 6 & 2 & 0 & 2 & 1 & 11 \\
\hline curtauli & Grani & M & $\mathrm{H}$ & 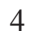 & 1 & 0 & 0 & 1 & 0 & 0 & 0 & 0 & 1 \\
\hline harpaffi & Grani & M & $\mathrm{X}$ & 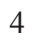 & 1 & 2 & 28 & 1 & 0 & 10 & 29 & 11 & 1 \\
\hline harp & Grani & M & M & 0 & 0 & 0 & 0 & 6 & 3 & 0 & 0 & 4 & 5 \\
\hline loripili & Pred & M & $\mathrm{H}$ & 3 & 1 & 0 & 0 & 3 & 1 & 0 & 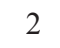 & 2 & 0 \\
\hline ophrrufi & Grani/Pred & M & $\mathrm{X}$ & 3 & 0 & 0 & 0 & 108 & 0 & 0 & 0 & 0 & 108 \\
\hline platassi & Pred & B & $\mathrm{M}, \mathrm{H}$ & 4 & 0 & 0 & 0 & 1 & 0 & 0 & 0 & 1 & 0 \\
\hline poeccupr & Grani/Pred & M & $\mathrm{M}, \mathrm{H}$ & 4 & 1 & 3 & 0 & 2 & 0 & 0 & 2 & 3 & 0 \\
\hline poecvers & Grani/Pr & M & $X$ & 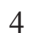 & 1 & 2 & 0 & 1 & 0 & 0 & 1 & 1 & 1 \\
\hline harprufi & Grani/Pred & M & M & 4 & 1 & 26 & 49 & 10 & 9 & 29 & 37 & 68 & 18 \\
\hline pterdili & Pred & $\mathrm{D}$ & $\mathrm{H}$ & 1 & 0 & 0 & 11 & 1 & 1 & 0 & 0 & 9 & 4 \\
\hline ptermela & Grani/Pred & $\mathrm{D}$ & $\mathrm{H}$ & 4 & 1 & 0 & 255 & 0 & 0 & 0 & 0 & 3 & 252 \\
\hline pternige & Pred & M & M & 4 & 1 & 0 & 1 & 0 & 0 & 0 & 0 & 0 & 1 \\
\hline pteroblo & $\mathrm{Pr}$ & M & $X$ & 4 & 1 & 0 & 0 & 2 & 0 & 0 & 0 & 0 & 2 \\
\hline pterstre & Pred & $\mathrm{D}$ & $\mathrm{M}, \mathrm{H}$ & 2 & 0 & 0 & 8 & 11 & 3 & 0 & 1 & 1 & 20 \\
\hline synttrun & Pred & $\mathrm{D}$ & X & 1 & 1 & 0 & 0 & 0 & 1 & 0 & 0 & 0 & 1 \\
\hline synuviva & Grani & $\mathrm{D}$ & & 3 & 1 & 1 & 2 & 0 & 0 & 0 & 0 & 1 & 2 \\
\hline trecmicr & Pred & M & $\mathrm{H}$ & 1 & 0 & 0 & 5 & 0 & 0 & 0 & 0 & 0 & 5 \\
\hline trecseca & Pred & B & $\mathrm{H}$ & 1 & 0 & 0 & 198 & 0 & 1 & 0 & 3 & 0 & 196 \\
\hline
\end{tabular}

